\title{
Penerapan Model Pembelajaran Inkuiri dengan Media Alat Peraga (Gunung Berapi) Pada Mata Pelajaran IPA SDN 013 Bengkulu Utara
}

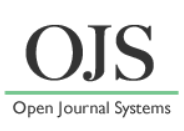

\author{
Mellyta Uliyandari ${ }^{1 *}$ dan Elly Efrida Lubis ${ }^{2}$ \\ ${ }^{1}$ Program studi Pendidikan IPA FKIP Universitas Bengkulu, Indonesia \\ ${ }^{2}$ Program Studi PGSD FKIP Universitas Terbuka, Indonesia \\ *E-mail: mellytaulan@gmail.com
}

DOI: https://doi.org/10.33369/pendipa.4.2.74-78

\begin{abstract}
[The Application of Inquiry Learning Model with Teaching Aids (Volcanoes) in Sciences Subject SDN 013 Bengkulu Utara] This study aims to improve the quality of student learning outcomes in science subjects class IV / B SDN 013 Bengkulu Utara, using inquiry methods and teaching aids (volcanoes). The participants in this study consisted of 24 students, 14 male students, and 10 female students. The study was conducted in 3 stages, namely: pre-cycle, cycle I, and cycle II where each cycle consisted of 4 stages: planning, implementing, observing, and reflecting. Inquiry learning in this study was carried out using teaching aids, with the aim that students could analyze and interpret their learning outcomes learned through simulations that had been carried out using teaching aids. In this study, each meeting ends with an evaluation in the form of test questions. The results of the analysis of mastery learning in pre-cycle are still quite low, namely, the results of students' mastery learning are only $33.33 \%$ with an average value of 64.79 After making improvements in learning in the first cycle classical learning completeness increased to $50 \%$ with an average value of 66.04. Then in the second cycle an increase of $95.85 \%$ with an average of 76.25. The results shows that the use of the inquiry method and teaching aids can improve student learning outcomes in science learning in SDN 013 Bengkulu Utara. This is due to the use of inquiry learning models with teaching aids can increase student motivation so that it affects the increase in student learning outcomes.
\end{abstract}

Keywords: Inquiry, Learning Media, Science.

\begin{abstract}
ABSTRAK
Penelitian ini bertujuan untuk meningkatkan kualitas hasil belajar siswa pada mata pelajaran IPA kelas IV/B SDN 013 Bengkulu Utara, menggunakan pembelajaran inkuiri dan media alat peraga (gunung berapi). Partisipan penelitian ini berjumlah 24 orang, terdiri dari siswa laki-laki sebanyak 14 orang dan siswa perempuan 10 orang. Penelitian di lakukan dalam 3 tahapan yaitu : prasiklus, siklus I dan siklus II dimana setiap siklusnya terdiri dari 4 tahapan yaitu : perencanaan, pelaksanaan, pengamatan dan refleksi. Pembelajaran inquiri dalam penelitian ini dilakukan dengan bantuan media alat peraga, sehingga siswa dapat menganalisis dan menafsirkan sendiri hasil pembelajaran yang dipelajari melalui simulasi yang telah dilakukan dengan bantuan alat peraga. Pada penelitian ini setiap pertemuan dilaksanakan evaluasi dengan memberikan soal-soal tes. Hasil analisis ketuntasan belajar pada prasiklus masih cukup rendah yaitu hasil ketuntasan belajar siswa hanya 33,33 \% dengan nilai rata-rata 64,79. Setelah melakukan perbaikan pembelajaran di siklus I ketuntasan belajar secara klasikal meningkat menjadi 50\% dengan nilai rata-rata 66,04. Kemudian pada siklus ke II terjadi peningkatan yaitu 95,85\% dengan rata-rata 76,25 . Hasil penelitian menunjukkan bahwa penggunaan model inkuiri dan media alat peraga dapat meningkatkan hasil belajar siswa pada pembelajaran IPA di SDN 013 Bengkulu Utara. Hal ini disebabkan penggunaan model pembelajaran inkuiri dengan media alat peraga dapat meningkatkan motivasi belajar siswa sehingga berpengaruh pada peningkatan hasil belajar siswa.
\end{abstract}

Kata Kunci: Inquiri, Media Pembelajaran, IPA. 


\section{PENDAHULUAN}

Pada pendidikan formal di Indonesia, Sekolah Dasar adalah jenjang paling dasar yang ditempuh dalam waktu enam tahun, mulai dari kelas satu sampai kelas enam dan merupakan suatu lembaga dengan organisasi yang tersusun rapi dan segala aktivitasnya direncanakan dengan sengaja yang disebut kurikulum (Ahmadi, 2001).

Proses belajar dan pembelajaran menjadi sesuatu yang sangat penting bagi anak-anak usia sekolah dasar, karena sekolah dasar memberikan bekal kemampuan dasar dalam aspek intelektual, sosial dan personal yang sesuai dengan karakteristik perkembangan anak usia 6 sampai 12 tahun. Menurut Djamarah (2008) belajar adalah serangkaian kegiatan jiwa raga untuk memperoleh suatu perubahan tingkah laku sebagai hasil dari pengalaman individu dalam interaksi dengan lingkungannya yang menyangkut kognitif, afektif, dan psikomotor. Sedangkan pembelajaran menurut Komalasari (2013), merupakan sistem atau proses membelajarkan pembelajar yang di rencanakan, di laksanakan dan di evaluasi secara teratur agar pembelajar dapat mencapai tujuan-tujuan pembelajaran secara efektif dan efisien.

Pelajaran IPA merupakan salah satu dari beberapa jenis mata pelajaran yang ada di sekolah dasar. Pelajaran IPA adalah suatu kumpulan teori yang teratur, penerapannya secara umum terbatas pada gejala-gejala alam, lahir dan berkembang melalui metode ilmiah seperti observasi dan eksprimen serta menuntut sikap ilmiah seperti rasa ingin tahu,terbuka, dan jujur (Trianto,2010). Mata pelajaran IPA memiliki beberapa tujuan yaitu agar peserta didik 1) Memiliki keyakinan tehadap kebesaran Tuhan Yang Maha Esa berdasarkan keberadaan, keindahan dan keteraturan alam ciptaan Nya; 2) Mengembangkan pengetahuan dan pemahaman konsep-konsep IPA yang bermanfaat dan dapat di terapkan dalam kehidupan sehari-hari; 3) Mengembangkan rasa ingin tahu sikap positif dan kesadaran tentang adanya hubungan yang saling mempengaruhi antara IPA, lingkungan, teknologi, dan masyarakat ; 4) Mengembangkan keterampilan proses untuk menyelidiki alam sekitar; 5) Meningkatkan kesadaran untuk berperan serta dalam memelihara,menjaga dan melestarikan lingkungan hidup; 6) Ikut serta memelihara menjaga dan melestarikan lingkungan, menghargai berbagai macam bentuk ciptaan Tuhan semesta ini untuk di pelajari (Sulistiyorini,2001).

Tujuan Pelajaran IPA dapat dicapai dengan menggunakan model dan media pembelajaran yang tepat. Model pembelajaran adalah seluruh rangkaian penyajian materi ajar yang meliputi segala aspek sebelum, sedang dan sesudah pembelajaran yang dilakukan guru serta segala fasilitas yang terkait yang digunakan secara langsung atau tidak langsung dalam proses belajar (Istarani,2011). Sedangkan media pembelajaran merupakan segala bentuk perangsang dan alat yang disediakan guru untuk mendorang siswa belajar secara cepat, tepat, mudah, benar dan tidak terjadinya verbalisme (Hanafiah \& Suhana,2010).

Banyak sekali jenis model dan media pembelajaran yang dapat digunakan dalam pembelajaran IPA di Sekolah Dasar, salah satunya adalah model pembelajaran Inkuiri. Model pembelajaran inkuiri adalah model pembelajaran yang dirancang untuk membimbing siswa bagaimana meneliti masalah dan pertanyaan berdasarkan fakta. Model inkuiri menekankan pada proses mencari dan menemukan, peran siswa dalam model ini adalah mencari dan menemukan sendiri pemecahan masalah dalam suatu materi pelajaran sedangkan guru sebagai fasilitator dan pembimbing siswa untuk belajar (Kardi, 2003).

Model pembelajaran inkuiri dianggap tepat digunakan dalam pembelajaran IPA di SD karena model inkuiri dianggap dapat membangkitkan rasa ingin tahu siswa, melibatkan siswa dalam kegiatan yang memerlukan keterampilan kognitif tingkat tinggi, memberikan pengalaman kongkrit bagi siswa, dan membantu siswa mengembangkan keterampilan proses. Model pembelajaran inkuiri yang digunakan adalah model pembelajaran inkuiri bebas (free inqury) dimana siswa dituntut untuk dapat mengidentifikasikan dan merumuskan berbagai macam persoalan yang hendak diselidiki secara berkelompok.

Media pembelajaran merupakan salah satu faktor penunjang yang cukup dominan dalam keberhasilan suatu proses pembelajaran. Penggunaan media dalam proses pembelajaran dapat membantu siswa memahami materi yang di 
ajarkan oleh guru. Salah satu media yang dapat digunakan dalam pembelajaran IPA di Sekolah Dasar adalah media alat peraga (Gunung Berapi)/ miniature gunung berapi.

Penggunaan model dan media yang tepat diaharapkan dapat meningkatkan hasil belajar siswa. Hasil belajar adalah perubahan tingkahlaku sebagai prestasi belajar dalam pengertian yang luas yang mencakup bidang kognitif, apektif, dan psikomotor (Sudjana,1995).

Penelitian ini dilakukan dengan menerapkan model pembelajaran inkuiri dengan media pembelajaran alat peraga (Gunung Berapi) pada pembelajaran IPA. Penelitian ini adalah jenis penelitian tindakan kelas, yang dilakukan untuk meningkatkan hasil belajar siswa Sekolah Dasar.

\section{METODE PENELITIAN}

\section{Waktu dan Lokasi Penelitian}

Penelitian ini dilakukan pada bulan april Mei 2018 pada siswa kelas IV/B SDN 013 Bengkulu Utara.

\section{Rancangan Penelitian}

Penelitian ini adalah penelitian tindakan kelas (PTK). Model pembelajaran yang digunakan adalah model pembelajaran inkuiri yang diharapkan dapat meningkatkan efektifitas perolehan hasil belajar siswa. Penelitian ini dilakukan dalam tiga tahapan yaitu tahap prasiklus, siklus satu, dan siklus dua. Setiap tahapan dilakukan empat tahap yaitu,perencanaan, pelaksanaan, pengamatan, dan refleksi (perenungan, pemikiran, evaluasi). Penelitian Tindakan Kelas adalah penelitian yang dilakukan secara sistematis reflektif terhadap berbagai "aksi" atau tindakan yang dilakukan oleh guru/pelaku, mulai dari perencanaan sampai dengan penilaian terhadap tindakan nyata didalam kelas yang berupa kegiatan belajar mengajar untuk memperbaiki kondisi pembelajaran yang dilakukan (Manurung,2008).

Pada penelitian ini tahap pra-siklus dilakukan dengan mengobservasi kegiatan belajar siswa di kelas dan memberikan refleksi terhadap kegiatan belajar yang telah dilakukan. Pada siklus satu dan dua, dilakukan perbaikan tindakan pembelajaran dengan menggunakan metode inkuiri dan media pembelajaran alat peraga (Gunung Berapi). Subjek pada penelitian ini adalah siswa kelas IV SDN 013 Bengkulu
Utara yang berjumlah 24 orang siswa,terdiri dari 14 orang siswa laki-laki dan 10 orang siswi perempuan

Tahap perencanaan pada penelitian ini dilakukan dengan menganalisis kurikulum untuk merancang pembelajaran menentukan $\mathrm{SK}, \mathrm{KD}$, indikator, tujuan pembelajaran yang sesuai dengan permasalahan yang dihadapi, menyusun silabus dan RPP, selanjutnya guru merancang skenario pembelajaran dengan menerapkan model pembelajaran inkuiri dan media pembelajaran berupa alat peraga (Gunung berapai), rubrik, dan evaluasi. Proses pembelajaran dilakukan sesuai dengan skenario pembelajaran. Tahap observasi dilakukan pada saat pembelajaran berlangsung dengan mengenali dan mendokomentasikan seluruh aktivitas pembelajaran dari proses awal sampai akhir yang dilakukan terus menerus dari prasiklus, siklus satu sampai siklus terakhir untuk mengetahui perubahan yang terjadi. Tahap refleksi dilakukan peneliti dan teman sejawat untuk mengevaluasi pembelajaran yang baru saja dilakukan. Mencermati data hasil pengamatan menemukan kelebihan dan kelemahan, serta memperbaiki atau menyempurnakan agar mencapai hasil yang diinginkan.

\section{Teknik Pengumpulan Data}

Teknik pengumpulan data pada penelitian ini dilakukan secara kualitatif dan kuantitatif. Data kualitatif berupa hasil observasi penulis dan data kuantitatif berupa tes tertulis dengan menggunakan soal-soal yang telah di validasi. Data tes hasil evaluasi siswa diukur dengan menentukan nilai rata-rata siswa setiap siklusnya dan menentukan persentase ketuntasan belajar siswa. KKM yang ditetapkan pada penelitian ini adalah 70 .

\section{Pengembangan Instrument}

Instrument pada penelitian ini berupa soal evaluasi (soal-soal tes dalam bentuk essai) yang dilakukan disetiap siklusnya. Validasi soal dilakukan dengan bantuan tim ahli (validator) dan uji coba soal. Uji coba soal meliputi analisis butir soal, reabilitas, taraf kesukaran, daya beda, distractor dan kemampuan kognitif siswa. 


\section{HASIL DAN PEMBAHASAN}

Penelitian ini bertujuan untuk meningkatkan hasil belajar siswa di setiap siklusnya dengan menerapkan model pembelajaran inkuiri dan media pembelajaran alat peraga (Gunung Berapi). Penelitian ini dilakukan pada siswa kelas IV SDN 013 Bengkulu Utara yang berjumlah 24 orang. Pada penelitian ini dilakuakn observasi yaitu pada tahap prasiklus. Hasil observasi menunjukkan bahwa guru di SDN 013 Bengkulu Utara masih menggunakan metode ceramah dalam menyampaikan materi pembelajaran. Hal ini lah yang diduga menjadi faktor penyebab hasil belajar siswa yang masih rendah. Pada Siklus pertama dilakukan perbaikan model pembelajaran dengan menggunakan model pembelajaran inkuiri, hasil yang diperoleh adalah rata-rata hasil belajar dan persentase ketuntasan belajar siswa meningkat namun belum maksimal, selanjutnya dilakukan siklus kedua dengan menerapkan model pembelajaran inquri bebas dan menggunakan media pembelajaran alat peraga (gunung berapi). Pada siklus kedua ini terjadi peningkatan yang cukup tinggi untuk rata-rata hasil belajar dan persentase ketuntasan belajar siswa.

Pada penelitian ini dilakukan evaluasi yang berupa soal-soal tes yang digunakan untuk melihat perkembangan hasil belajar siswa di setiap siklunya. Nilai rata-rata yang diperoleh siswa untuk setiap siklus dapat dilihat pada Gambar 1 di bawah ini:

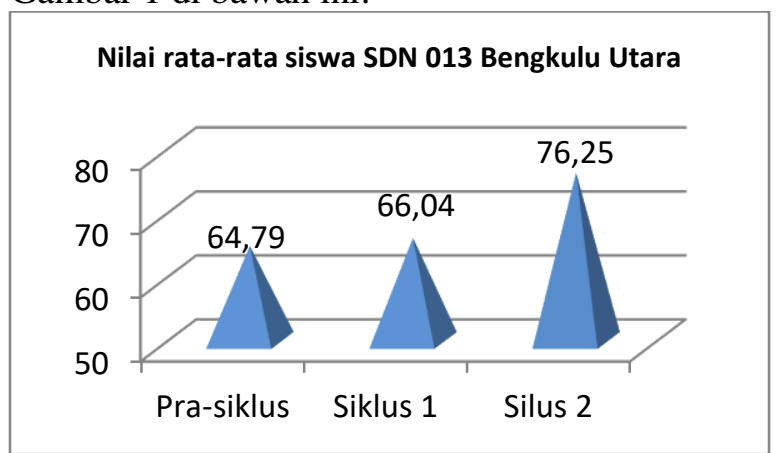

Gambar 1. Histogram nilai rata-rata siswa SDN 013 Bengkulu Utara

Berdasarkan gambar 1, terjadi peningkatan hasil belajar siswa disetiap siklusnya. Pada tahap pra-siklus nilai rata-rata hasil belajar siswa 64,79. Pada silus satu terjadi peningkatan menjadi 66,04. Pada siklus kedua terjadi peningkatan kembali menjadi 76,25.
Persentase ketuntasan belajar siswa disetiap siklus pembelajaran juga mengalalami peningkatan, seperti tertera pada gambar di bawah ini:

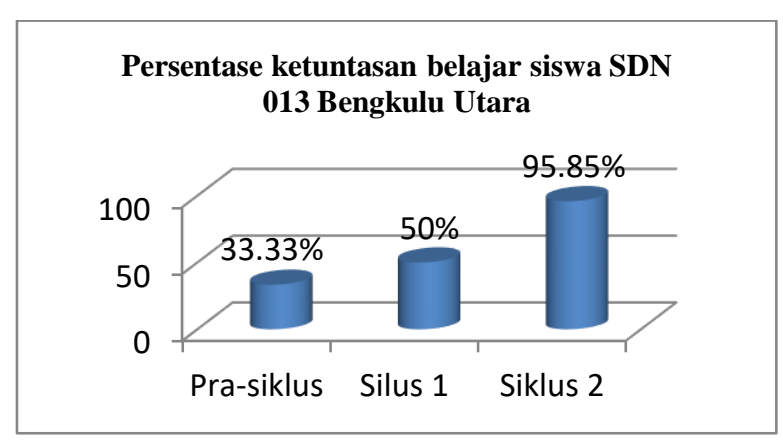

Gambar 2. Histogram persentase ketuntasan belajar siswa SDN 013 Bengkulu Utara

Pada gambar 2, persentase hasil belajar pada tahap pra-siklus adalah 33,33\% dengan jumlah siswa yang nilainya melampaui KKM sebanyak 8 orang. Pada siklus satu meningkat menjadi $50,00 \%$, dengan jumlah siswa yang melampaui KKM sebanyak 12 orang dan pada siklus kedua persentase hasil belajarnya semakin meningkat menjadi 95,85\% dengan jumlah siswa yang tuntas atau melampaui KKM sebanyak 23 orang. Setiap siklusnya terjadi peningkatan persentase hasil belajar.

Berdasarkan gambar 1 dan gambar 2 diketahui nilai rata-rasa siswa berbanding lurus dengan persentase ketuntasan belajar siswa di SDN 013 Bengkulu Utara. Skor minimal mencapai kriteria ketuntasan belajar (KKM) yang digunakan sebesar 70 .

Pada penelitian ini secara keselurhan terjadi peningkatan hasil belajar siswa yang ditandai dengan bertambahnya persentase ketuntasan siswa disetiap siklusnya. Pada siklus kedua hanya ada satu orang siswa yang nilainya masih berada dibawah KKM, hal ini kemungkinan disebabkan beberapa faktor seperti kemampuan pemahaman siswa yang memang agak sedikit kurang, atau bisa juga diakibatkan kurang fokusnya siswa dalam mengikuti proses pembelajaran.

Peningkatan hasil belajar secara keseluruhan disetiap siklusnya, diduga dipengaruhi oleh penerapan model pembelajaran inkuiri yang menekankan pada proses mencari dan 
menemukan, peran siswa dalam model ini adalah mencari dan menemukan sendiri pemecahan masalah dalam suatu materi pelajaran sedangkan guru sebagai fasilitator dan pembimbing siswa untuk belajar. Dengan menemukan sendiri pemecahan masalah yang sedang dihadapi, siswa diharapakan dapat membangun pemahaman berdasarkan pengalaman.

Pada penelitian ini juga digunakan media pembelajaran yang berupa alat peraga (Gunung berapi). Media pembelajaran yang digunakan, diduga menjadi salah satu faktor penunjang meningkatnya hasil belajar siswa. Penerapan model pembelajaran inkuiri dan media alat peraga yang tepat menjadi kesatuan yang kompleks untuk meningkatkan hasil belajar siswa.

\section{KESIMPULAN}

Berdasarkan hasil penelitian dapat disimpulkan bahwa penerapan model pembelajaran inkuiri dan penggunaaan media pembelajaran alat peraga (gunung berapi) dapat meningkatkan hasil belajar siswa SDN 013 Bengkulu Utara. Hasil belajar dan persentase ketuntasan belajar siswa mengalami peningkatan di setiap sisklusnya, namun jika dilihat berdasarkan data, siklus II memiliki potensial yang cukup tinggi untuk meningkatkan hasil belajar dan persentase ketuntasan belajar siswa. Hali ini dapat dilihat dari kenaikkan nilai ratarata hasil belajar siswa dan persentase ketuntasan belajar siswa disetiap siklusnya, tahap pra-siklus $64,79(33,33 \%)$, siklus satu 66,04 $(50,00 \%)$, siklus dua 76,25 $(95,85 \%)$.

\section{DAFTAR PUSTAKA}

Ahmadi, Abu. 2001. Ilmu Pendidikan. Jakarta: Rineka Cipta.

Djamarah, S. B.2008. Strategi Belajar Mengajar. Bandung: Rineka Cipta

Hanafiah dan Suhana. 2010. Konsep Strategi Pembelajaran. Bandung: PT Refika Aditama.

Istarani, 2011. Model Pembelajaran Inovatif (Reverensi Guru Dalam Menentukan Model Pembelajaran). Medan : Media Persada

Kardi, Soeparman. 2003. Merancang Pembelajaran Menggunakan Model Inkuiri. UNS, Surabaya.

Komalasari,Kokom. 2013. Pembelajaran Kontekstusi Konsep dan Aplikasi. Bandung : PT Refika Adiatama.

Manurung, M.2008. Penelitian Tindakan Kelas. Jakarta: PT. Gramedia Widiasarana Indonesia.

Sudjana, Nana. 1995. Penilaian Hasil Proses Belajar Mengajar. Bandung : PT. Remaja Rosda Karya.

Sulistiyorini .2007. Model Pembelajaran IPA SD dan Penerapan Dalam KTSP Global Pustaka Ilmu :Jogyakarta.

Syaiful,Sagala. 2006. Konsep dan Makna Pembelajaran. Bandung: Alfabeta

Trianto, 2010. Model Pembelajaran Terpadu. Jakarta: Bumi Aksara. 